\title{
A blue catalase screening test for pyuria and haematuria
}

\author{
MAIR THOMAS AND GILLIAN BALDWIN
}

From the Epidemiological Research Laboratory, Central Public Health Laboratory, Colindale, and the Elizabeth Garrett Anderson Hospital, London

SYNOPSIS The blue catalase test is easy to perform and economical of materials. In a series of $52 £$ adult female hospital patients it appeared to be a good screening test for pyuria and haematuria $\leftarrow$ detecting all but one of the specimens examined with more than 20 red and white cells combine $f$ per cubic millimetre of urine and $95.2 \%$ of those with more than 10 cells. It indicates a raised్d leucocyte or red cell excretion rate but is not a test for bacteriuria.

The clinical importance of a raised leucocyte excretion rate was demonstrated by Fairley and Barraclough (1967) and Gower, Haswell, Sidaway, and de Wardener (1968). More recently MacLeod (1970) has reported the significance of minimal haematuria as a sign of unsuspected urinary tract disease in general practice. The test to be described selects those urine specimens in which microscopy is likely to be profitable. For this purpose it was considered that urine containing 10 or more red cells or leucocytes per $\mathrm{mm}^{3}$ should give a positive result. Ten leucocytes corresponds with the maximum normal excretion rate defined by Little (1962 and 1964). Two red cells is at the upper limit of the normal Addis count (Sunderman and Boerner, 1949).

The principle of the modified catalase test to be described is that the bubble trap formed between a glass tile or slide and a coverslip makes visible very small volumes of oxygen gas released from a coloured peroxide solution by the action of catalase present in the products of inflammation or bleeding in the urinary tract. It is an application of the blue peroxide slide catalase test (Thomas, 1963). Fresh or refrigerated urine can be tested.

\section{Method}

\section{MATERIALS}

The reagent is prepared by adding 1 part of aqueous methylene blue to 4 parts of 20 volume hydrogen peroxide in a dark glass eyedropper bottle. This is stable for months in the refrigerator and weeks on the shelf.

Received for publication 15 July 1970.
The apparatus consists of a bacteriological loo calibrated to deliver $12 \mathrm{~mm}^{3}$ ( $25 \mathrm{SWG}$, internab diameter of $5 \mathrm{~mm}$ ) and a slide or a white glass tile permanently ruled into numbered squares of about $3 \mathrm{~cm}$ side. It is convenient to have about 12 square on a tile. The last square should be marked 'control?

TECHNIQUE

Use the loop to put $12 \mathrm{~mm}^{3}$ of one urine in each square. With the eyedropper pipette add a drop of reagent to each loopful of urine. End with a control drop of reagent alone.

With a fine forceps lower a coverslip delicateli over each preparation, taking care not to create adventitious bubbles.

Stand for 10 minutes by the alarum clock.

Mark as positive preparations showing white bubbles (Fig. 1). The control should remain negative. (Occasionally in warm weather or with 8 deteriorating reagent a trace of bubbling mas develop in the reagent control, but catalase-positiv urines will show much more reaction.) After reading the tile is rinsed in $4 \%$ Lysol for 30 seconds and then washed and dried ready for use again.

\section{APPLICATION}

Clean-catch midstream urine from 529 adult femade hospital patients with a variety of diagnoses wiक examined chemically and bacteriologically by direct microscopy and by the blue catalase test. The results of the catalase test were tabulated with the record of microscopy and the results of a chemical test for blood (Labstix, Ames). The results were analysef mechanically and are shown in Tables I to IV.

Finally, the number of minutes taken to screen 
$+\quad$ Neg. Neg.
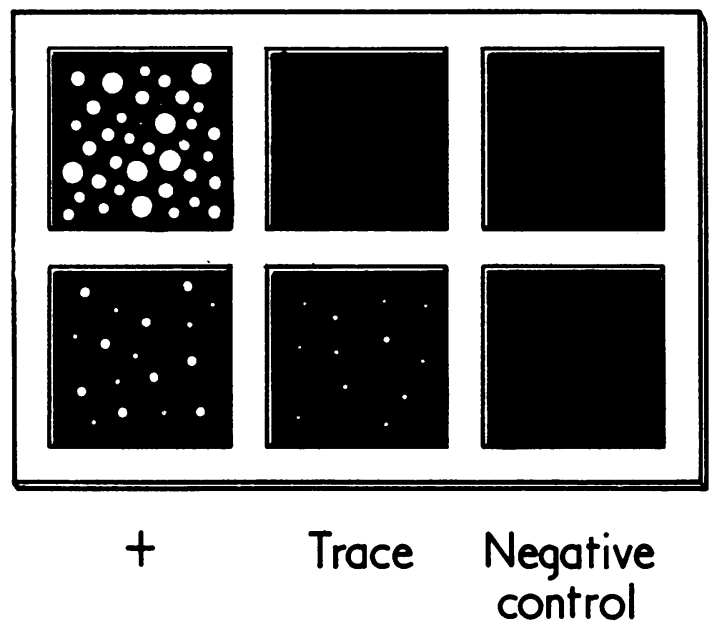

Fig. 1 Positive preparations show white bubbles.

urines by the blue catalase test, including time taken for microscopy of the catalase-positive proportion of specimens, was compared with the time taken for direct microscopy of all specimens.

\section{Results}

Ten or more red cells or leucocytes per cubic

\begin{tabular}{llllr}
\hline Cells & \multicolumn{2}{l}{ Catalase Test } & Total \\
\cline { 2 - 4 } & Strong Positive & Trace & Negative \\
\hline None & 48 & 44 & 255 & 347 \\
Red cells $10+\mathrm{mm}^{3}$ & 40 & 2 & 2 & 44 \\
$\quad<10 \mathrm{~mm}^{3}$ & 4 & nil & 7 & 11 \\
Pus cells $10+\mathrm{mm}^{3}$ & 69 & 8 & 4 & 81 \\
$\quad<10 \mathrm{~mm}^{3}$ & 22 & 4 & 20 & 46 \\
Total & 183 & 58 & 288 & 529 \\
\hline
\end{tabular}

Table I Relationship between catalase test and cells in urine

\begin{tabular}{lll}
\hline Case & No. of Pus Cells $/ \mathrm{mm}^{3}$ & No. of Red Cells $/ \mathrm{mm}^{3}$ \\
\hline 1 & 110 & - \\
2 & 15 & - \\
3 & 5 & - \\
4 & 20 & - \\
5 & 15 & - \\
6 & 15 & \\
\hline
\end{tabular}

Table II Findings in the catalase-negative urines in which 10 or more cells were seen millimetre of urine were recorded in 125 of the 529 specimens $(23.6 \%)$. The blue catalase test was positive in 119 of these $125(95.2 \%)$ and negative in six (Table I). Five of these six specimens had 20 or fewer combined red and white cells per $\mathrm{mm}^{3}$, while one had 110 leucocytes. Thus only one out of 63 specimens with more than 20 cells per $\mathrm{mm}^{3}$ was missed (Table II).

The test was also positive in $\mathbf{3 0}$ of $\mathbf{5 7}$ urines with less than 10 cells per $\mathrm{mm}^{3}(53 \%)$ and in 92 of 347 with no cells $(26.5 \%)$.

Table III shows findings in these 92 catalasepositive specimens without cells. A chemical test for blood (Labstix) was positive in one third. Conversely, this chemical test detected $91 \%$ and the blue catalase test $95 \%$ of specimens containing 10 or more red cells per $\mathrm{mm}^{3}$ (Table IV).

The specificity and sensitivity of the test were calculated (Vecchio, 1966). The specificity for wholly cell-free urines was $73 \%(255 / 347)$ and for urines both cell-free and blood-negative by Labstix it was $81 \%(255 / 315)$. The sensitivity was $98 \%$ $(62 / 63)$ for urines with more than 20 combined red and white cells per $\mathrm{mm}^{3}, 95 \%(119 / 125)$ for 10 or more cells, and $82 \%(149 / 182)$ for any cells visible.

There were 241 positive and 288 negative catalase tests. The time taken for a cell count was over two minutes and the time per catalase test was under one minute. Catalase-negative urines were therefore screened in less than one minute, while positive specimens required an additional two to three minutes for microscopy, making a total of about three minutes. The time gained by omitting micro-

\begin{tabular}{|c|c|c|c|c|c|c|}
\hline \multirow[t]{2}{*}{ Catalase } & \multicolumn{3}{|c|}{ Labstix Test } & \multirow{2}{*}{$\begin{array}{l}10^{5} \\
\text { Bacteria } \\
\text { per } \mathrm{ml}\end{array}$} & \multirow{2}{*}{$\begin{array}{l}\text { None } \\
\text { of the } \\
\text { Preced- } \\
\text { ing }\end{array}$} & \multirow[t]{2}{*}{ Total } \\
\hline & Blood & $\begin{array}{l}\text { Blood } \\
\text { and } \\
\text { Protein }\end{array}$ & Protein & & & \\
\hline $\begin{array}{l}\text { Strong positive } \\
\text { Trace }\end{array}$ & $\begin{array}{r}17 \\
6\end{array}$ & $\begin{array}{l}9 \\
0\end{array}$ & $\begin{array}{l}1 \\
2\end{array}$ & $\begin{array}{r}13 \\
6\end{array}$ & $\begin{array}{r}8 \\
30\end{array}$ & $\begin{array}{l}48 \\
44\end{array}$ \\
\hline Total & 23 & 9 & 3 & 19 & 38 & 92 \\
\hline
\end{tabular}

Table III Findings in catalase-positive urines in which no cells were seen

\begin{tabular}{lrcrc}
\hline & \multicolumn{2}{c}{ Catalase Reaction } & Total \\
\cline { 2 - 4 } & Negative & Trace & $\begin{array}{l}\text { Strong } \\
\text { Positive }\end{array}$ \\
\hline Labstix + red cells seen & 2 & 3 & 43 & 48 \\
Labstix + no red cells seen & 18 & 10 & 47 & 75 \\
Labstix - red cells 10+ mm & 2 & nil & 11 & 13 \\
Labstix - red cells <10 mm & 5 & nil & 9 & 14 \\
Labstix - no red cells & 261 & 45 & 73 & 379 \\
Total & 288 & 58 & 183 & 529 \\
\hline
\end{tabular}

Table IV Relation of Labstix blood test to red cells in urine 
scopy on catalase-negative specimens was just over a minute each. That lost by performing the test on positive specimens was just under a minute each. When the proportion of catalase-negative specimens in a batch exceeded $50 \%$ the test clearly saved time.

\section{Discussion}

The blue catalase test described was positive when significant numbers of red or white cells were present in the urine, that is to say, when the urinary leucocyte or red cell excretion rate was raised (Little, 1962 and 1964). The technique is rapid and simple. Clean-catch urine is used and the vagina can be plugged with paper tissue to avoid contamination. Only small quantities of urine and of a cheap and stable reagent are required. There is no need for microscopy of negative specimens and the time saved can be more usefully applied to accurate cell counts for the remainder (Houston, 1969). Time is saved significantly when more than $50 \%$ of a batch are negative. This was usual in our hospital series and a much higher proportion of negatives would be expected when healthy populations are screened (Meadow, White, and Johnston, 1969).

An analysis showed that $95 \%$ of urines with 10 cells, and nearly all (98\%) those with more than 20 cells per $\mathrm{mm}^{3}$ gave a positive reaction, while $73.5 \%$ of urines without cells were negative. We believe that other catalase tests have been misapplied to the diagnosis of bacteriuria, but that the screening test we have described is a reliable one for pyuria and haematuria and is therefore a pointer to other urological abnormalities as well as to infection (Fairley and Barraclough, 1967). We use it in conjunction with a standard bacterial enumeration method (Leigh and Williams, 1964) and the centrifugation of protein-positive urines to be examined for casts.

It seems probable that the catalase detectable in urine specimens is, as in the mastitis of cattle, mainly derived not from bacteria but from bleeding or from the products of inflammation, notably red cells and leucocytes (Nagaswararao, Derbyshire, and Berman, 1969). Naturally when bacterial infection is associated with inflammation, catalase tests are likely to be positive. However, very different orders of reliability have been reported in the detection of significant bacteriuria with false negative results ranging frome $6.3 \%$ (Lie, 1967) to $57 \%$ (Kincaid-Smith, Bullen? Fussell, Mills, Huston, and Goon, 1964). Wren (1969), reviewing results obtained with flotation andw? tube catalase, TTC and Griess nitrite screening tests? concluded that none of them were satisfactory as al yielded too many misleading negatives. We concuis with this view as regards bacteriuria. The blue catalase test we have described was negative in $20^{\circ} \mathrm{m}$ of urines in our series which had a bacterial count of $10^{5}$ or more per $1 \mathrm{ml}$ and also in some urines ex perimentally infected with $10^{6} \mathrm{E}$. coli. Bacteriuria should be sought separately by appropriate methods such as the dip-slide described by Guttman anf Naylor (1967).

Our thanks are due to Mr W. B. Fletcher, Mrs G. V: Smith, and Miss Hilary Mogford for analytica assistance.

\section{References}

Fairley, K. F. and Barraclough, M. (1967). Leucocyte-excretion rateas a screening test for bacteriuria. Lancet, 1, 420-421.

Gower, P. E., Haswell, B., Sidaway, M. E., and Wardener, H. E. de (1968). Follow-up of 164 patients with bacteriuria of pregnancy. Lancet, 1, 990-994.

Guttman, D., and Naylor, G. R. E. (1967). Dip-slide: an aid to quantitative urine culture in general practice. Brit. med. J., 3, 343-345.

Houston, I. B. (1969). Measurement of pyuria in urinary tract in fections. Arch. Dis. Childh., 44, 480-482.

Kincaid-Smith, P., Bullen, M., Fussell, U., Mills, J., Huston, N., an\$ Goon, F. (1964). The reliability of screening tests for bacteriuria in pregnancy. Lancet, 2, 61-62.

Leigh, D. A., and Williams, J. D. (1964). Method for the detectioß of significant bacteriuria in large groups of patients. J. clin Path., 17, 498-503.

Lie, J. T. (1967). Urinary catalase testing: A simple screening test for significant bacteriuria. Med. J. Aust., 2, 497-499.

Little, P. J. (1962). Urinary white-cell excretion. Lancet, 1, 1149-115

Little, P. J. (1964). A comparison of the urinary white cell concertration with the white cell excretion rate. Brit. J. Urol., 367 360-363.

MacLeod, M. (1970). Routine urine tests in general practice. Lance 1, 1167-1168.

Meadow, S. R., White, R. H. R., and Johnston, N. M. (1969). Prevalence of symptomless urinary tract disease in Birminghang school children. I. Pyuria and bacteriuria. Brit. med. J., 3 81-84.

Nagaswararao, G., Derbyshire, J. B., and Berman, D. T. (1969 Sources and mechanism of catalase activity in the catalase test for abnormal milk. J. Milk Tech., 32, no. 7, 261-264.

Sunderman, F. W., and Boerner, F. (1949). Normal Values in Clinical Medicine, p. 365. Saunders, Philadelphia.

Thomas, M. (1963). A blue peroxide slide catalase test. Month. Bu/Ro Minist. Hlth. Lab. Serv., 22, 124-125.

Vecchio, T. J. (1966). Predictive value of a single diagnostic test unselected populations. New Engl. J. Med., 274, 1171-1173.

Wren, B. G. (1969)). The diagnosis of asymptomatic bacilluria if pregnancy. Med. J. Aust., 1, 117-121. 